\title{
Teacher Professionalism and Professional Development Practices in South Sulawesi, Indonesia
}

\author{
Hasan Tanang ${ }^{1, *}$ \& Baharin Abu $^{1}$ \\ ${ }^{1}$ Education and Development, Faculty of Education, Universiti Teknologi Malaysia, Johor, Malaysia \\ *Corresponding author: Melawis Apartment, Jln. Pendidikan 1, M2-078, 81300, Skudai, Johor Bahru, Johor, \\ Malaysia. Tel: 60-113-653-3494. E-mail: h.hasan20@yahoo.com.sg
}

Received: June 1, 2014

Accepted: June 23, $2014 \quad$ Online Published: July 7, 2014

doi:10.5430/jct.v3n2p25

URL: http://dx.doi.org/10.5430/jct.v3n2p25

\begin{abstract}
This study investigates teachers' professionalism and professional development practices which still have lower quality based on the law and do not produce an improved performance yet in South Sulawesi, Indonesia. This investigation focuses on teachers' behavior-attitude, pedagogic skills, and diversity learning activities through effective professional development as commitment to do continuous improvement. The supporting factors and the constraints of being professional teacher are also identified. The design of this study employs exploratory mixed method design with triangulation approach. Simple random sampling is occupied in choosing 331 samples out of 2367 population to answer the questionnaires. While twelve teachers were selected using purposive sampling for interview and observation. The t-test and Anova analysis show that gender has significant different in behavior-attitude practice, while education professional qualification is significant on both behavior-attitude and teachers' learning activities. The qualitative findings show the need to display exemplary behavior-attitude, strength teaching skill, knowledge and beliefs through diversity learning activities in effective professional development. Teacher professional development needs supporting on policy, moral, infrastructure, and financial that can lead teachers to be professional. This study has provided a model of teacher professional development as an input for improving the quality practice of teacher professionalism and professional development in Indonesia, particularly in South Sulawesi province.
\end{abstract}

Keywords: teacher professionalism; professional development

\section{Introduction}

The main challenge of the Indonesian nation is the capability to improve its human resources quality and education sector (Kemendiknas, 2010). Based on United Nation Development Program (UNDP) report in 2011, Indonesia is still in ranking 124 of 187 countries for human development index. Further, this organization identified that one challenge is the low level of Indonesian education which affect directly to society's quality and ability. Since that, the government invests in education as a strategy to develop high quality human resources. Quality education must be supported by professional teachers to produce the people who have life skills and strong self-confidence to be competitor among other people in global life.

The efforts above also outlined in Indonesian constitution which guarantees to empower and to improve the quality of teachers continuously. It ensured the access for quality improvement and relevance, as well as good governance and accountability of teachers to face the challenges in local, national, and global level. The government of Indonesia also needs to foster Continuous Professional Development (CPD) to cope ongoing changes effectively to advance the quality of teachers. That is why, the opportunity to improve their professionalism through profession development is guaranteed by law (UUGD, 2005). Furthermore, strengthening and promoting member's professional development is expected to diminish the gap of the existing bureaucracy. Professional development helps teachers to construct their lifelong learning to achieve better achievement.

Therefore, this study is to investigate the teacher professionalism and professional development as being practiced to find out a model of professional teachers development at senior high school in South Sulawesi, Indonesia. 


\section{Background of Problem}

Teachers play an important role in teaching and learning process to improved student outcomes although many factors contribute to their success (Rivkin, Hanushek, \& Kain, 2000; Sanders \& Horn, 1994; Sanders \& Rivers, 1996; Boyd, 2006). The students learning achievement depends on the readiness of teachers to do learning activities which are supported by teacher's knowledge and skills, attitude and practice. That is why most of the literatures require a teacher to possess good competences and performance, involve in professional development actively, engage knowledge with the current issues, conduct the tasks ethically, and show commitment or responsibility in teaching practice at school. These five dimensions had also been identified by Sockett (1993) and Tichenor and Tichenor (2005) to analyze the quality practice of teachers. In supporting their role, teachers also require to engage learning opportunity in professional development such as workshop, mentoring, and training by using different resources to link the outcomes with the goals of education in providing knowledge, skills, and fine attitude to participate in society positively.

A study about general competency of many teachers in Indonesia reported by World Bank (2010) showed that their education attainment still lower than bachelor degree. The 2012 data of Indonesian Education Ministry indicate that just 487.488 (81.21\%) of 600.374 teachers of senior high school hold bachelor degree or four-year diploma and the rest 112.888 (18.79\%) still hold Diploma degree. The report also explains that teachers have low competency score test on subject knowledge, pedagogic skills, and general academic aptitude. Even though this test is not nationally scale, the average teachers only scoring below 50 percent. In addition, a serious concern of Indonesian teachers is the low level of professional knowledge, skills, motivation, and efforts. A survey which is focus in teacher absenteeism, for instance, one in five teachers absent from the class and civil servant get 12.5 percent (SMERU, 2008). All the cases above associated with more responsibility, commitment, and self-learning behavior, and the ethic obedience of teachers.

The low level of teacher education attainment in current profession is the impact of prior recruitment conditions that require a high school degree and diploma degree to enter the profession (Bjork, 2003). It is the argued whether these qualifications enough for teachers to own knowledge and skills to meet the need of students. It is contrast with most top-performing countries such as Singapore just recruits the candidates who have best academic performance and Finnish government makes their teacher to be trusted and respected by having master degree (Tuovinen, 2008). The belief is argued by Rout (2007) that teacher education can help a lot the system of learning. That is why the upgrading of academic background to bachelor degree as minimum standard becomes a great intention of Indonesian government. Through teacher certification policy, all teachers are targeted hold bachelor or four-year degree in 2015.

What is more, the Ministry of Education should find out the solution of some symptoms that indicate the low quality of Indonesian teachers. Formerly, Sudarminta (2000) had exposed the weaknesses of some teachers in the class room such as; (i) lack of mastery of the material being taught, (ii) mismatch between teachers' subject areas studied and taught, (iii) lack of effective ways of teaching and authority in front of students, (iv) low motivation and dedication to become a real educator, (v) lack of emotional maturity, independence of thought, and attitude determination of being educators, most teachers are still only serves as a teacher and not as an educator; (vi) relatively low intellectual level of students entering teacher candidates LPTKs (Institute of Personnel Procurement) compared to those entering the university. For the shortcomings, Ingersoll (2007) suggested to the policy makers focus on two general approaches; firstly, ensuring all subjects are taught by qualified teachers through upgrading the teacher's qualification and secondly, supplying the less subject-teacher by recruiting new qualified teachers or doing resettlement from a surplus to a deficit one.

In addition, the policy makers might not realize that teachers are working in a poor work environment. So, teacher also has concerns toward the public and the government to overcome the limitations within the profession in order to enhance the quality. Teacher has lack of autonomy by the strict bureaucracy control, the limited time and financial support to have professional development, a minimum reward to appreciate teacher's great work, the availability of facilities and supporting resources such as technology and good learning environment to facilitate teaching, access teaching sources, and related information. An indication was reported by Ali (2000) where teachers felt to be pressured by Ministry of National Education to cover and to transfer the prescribed curriculum and content-subject. This is strengthened by UNESCO's report (2006) that inadequate resources and facilities threatening the improvement quality of education in Indonesia.

Susilo Bambang Yudhoyono, president of the Republic of Indonesia (2012) expressed his concern in teachers' day. He stated that most of the teachers have additional incentive from certification as professional teacher, more incomes from local and central government, and more training but they still show unstable commitment and enthusiasm 
toward their job. More treatments to construct their attitude and behavior such as policy and bureaucracy system are required to fulfill their needs in teaching. The authorities in education, the school supervisor and the principal also need to support them and to have reflection regularly in order to encourage their commitment, expertise, and inspiration in teaching. Toh et al. (2006) and Watt \& Richardson (2008) believed that teacher's commitment and motivation are very significant to behavior of teacher.

Meanwhile, a research by Misbahuddin (2013) found that the factors inhibiting the development of teacher profession in South Sulawesi, namely; the lack of awareness of teachers in developing the profession continuously, felt had sufficient capacity so as not serious in the training, less benefit for the development of competence in teaching because the participants have irrelevant basic skills, and lack of attention from local government to the activities of Teacher-Subject Forum or MGMP. In line with Nielsen's (1996) finding in Indonesia that some of participants in professional development are different with their basic knowledge which is resulting useless things for their competence development in teaching.

Generally, there are many unqualified teachers in South Sulawesi because of the limited access and resources especially in the rural areas. They rarely get formal training and update curriculum that hindered their knowledge and teaching skills (Saluling, 2009). Until now, Teacher training becomes a challenge in supporting teacher professionalism because the government has limitation to hold it. The government of Indonesia tries to build the education quality by strengthening training for teacher, but it has not found the level of commitment and investment in professional development of teachers did not produce an improved performance (Nielsen, 1996). Overall, the focus of training originates from a reflection and evaluation, the theory and practice taught in training must be relevant to school needs and emphasis more on method and practice of teaching.

\section{Improving Teacher Professionalism to Adapt the Challenges}

In Indonesian context, teacher professionalism based on the national policy related to the ability of teachers in conducting their role and function and how they behave at school and in society context. The Law of Teachers and Lecturers No. 14 Year 2005 mandates teachers as professional educators with the primary task of educating, teaching, guiding, directing, training, assessing, and evaluating students on early childhood education, formal education, primary education, and secondary education. The law required people who have talents, interests, vocation, and idealism; committed to improving the quality of education, faith, piety, and noble character; academic qualifications and educational background in accordance with its assignment; necessary competence in accordance with its duties; responsibility for the professionalism of the performance of duties; income determined in accordance with job performance; opportunity to develop in a sustainable manner with the professionalism of lifelong learning; guarantee of legal protection in carrying out the duties professionalism; and professional organization that authorize to regulate matters relating to the task of teacher professionalism.

In carrying out professionalism duties, teacher obliges to meet certain quality standards or norms and require professional education. Teachers must be own live, and control knowledge, skills, and behaviors as a set of competence. They require to have academic qualification of a bachelor or four-years-diploma level of academic education to be possessed by the teachers in accordance with the type, level, and formal education units in where the assignment. Certification is also obligated as the process of granting certificates to teachers and teacher educators according to the Teachers Law. Educator certificate is evidence of formal recognition given to teachers and teachers as professionals by the state.

Research and Education Development of Indonesian Education Department relates the professionalism of teachers to the ability of teachers' knowledge, attitudes and skills in educating and teaching therein including the ability to understand students. The department suggests that to increase professionalism, teachers should engage in activities that include: education, teaching and learning process and professional development. According to experts, professionalism is emphasizing the mastery of knowledge management capabilities and its strategy or its implementation. Maister (1997) suggests that professionalism is not just knowledge of technology and management, but more of an attitude. Professional is more than a technician not only has high skills but own a behavior that required. Supriadi (1998) explains that to be professional a teacher is required to have five things: (1) teachers are committed to students and their learning, (2) teachers in-depth mastering the subjects and how to teach, (3) responsible to monitor student learning outcomes through various means of evaluation, (4) able to think systematically, and (5) teachers should be a part of the learning community within the profession.

The profession of teacher also has some rights in carrying out their professionalism as a responsibility to the 
profession, government, and public. In this case, teachers will be facilitated as public servicers to have maximum income and good social welfare; get promotions and awards in accordance with duties and job performance; obtain protection in carrying out the duties and rights of intellectual property; the opportunity to improve competence; obtain and utilize the learning infrastructure to support the smooth professionalism of the task; have freedom in their assessments, have graduation, awards, and/or sanctions to students based on rules of education, teacher's code of ethic, legislation, and regulation, gain a sense of security and safety assurance in performing the tasks, have the freedom to associate in professional organizations; have the opportunity to play a role in determining educational policy, the opportunity to develop and improve the academic qualifications, competence, and training and professional development in the field.

Professionalism as a support of teacher fluency in performing their duties, greatly influenced by the development and policy employed. Today, Indonesian teachers are challenged to adapt the revolution of technology information in improving their professionalism. The development of information technology will change the pattern of teacher-pupil relationship, models of learning, and the educational system as a whole. Information and Communication Technology (ICT) should be used in education to achieve the goal rather than as a barrier. The role of the teacher will not be the only source of learning because many learning resources and sources of information can facilitate a person to learn. Schools are no longer going to be the only centre of learning because learning activities are no longer limited by space and time.

Next, Indonesian development paradigm has shifted from centralized to decentralized paradigm since 2003. It aims to increase the participation of the people in supporting teacher development and to train them in managing their own affairs. Learning from past experiences where the government is more powerful that the marginalized society in the development process. Decentralization implies that teachers should be place as actors and beneficiaries of the process of finding a solution and achieve development outcomes for themselves and their environment in a broader sense. Thus, teachers should be able to improve the quality of self-reliance to overcome his problems, both individually and collectively.

\section{Professional Development in Professionalizing Teacher}

As mention above that in addition to the improving teachers' qualification and obligating certification, teachers need opportunity to involve in the professional development in order to maintain and grow up their knowledge, skills, and practice. The kinds of professional development have been made in Indonesia to improve teacher professionalism such as, PKG (Pusat Kegiatan Guru or Centre for Teacher Activity), KKG (Kelompok Kerja Guru or Teachers Working Group), and MGMP (Musyawarah Guru Mata Pelajaran or Forum of Teacher-subject) that allow teachers to share their experiences in solving the problem they face in teaching activities (Supriadi, 1998). The other forms of professional development held for teachers are training and workshop with generally or specifically purposes. The programs proposed in it will be melting the daily-faced problem in learning and teaching and improve teachers' innovation and creativity for the successful of the students.

Teacher-subject forum (MGMP) is the most familiar of professional development among teachers in Indonesia because it covers the whole areas geographically from urban to the rural. The empowerment of MGMP must be interpreted as a process that continues to live, grow, and evolve over time. Empowerment through continuous and sustained, MGMP expected to act as a reformer in the classroom reform, mediator in the development and improvement of teacher competence, the agent "encouragement" in classroom management innovation and school management, as well as collaborators of the unit concerned and the relevant professional organizations (USAID-DBE3, 2005). MGMP success in empowering themselves will be strongly influenced by the work ethic of all trustees, members, and teachers of similar subjects in building the spirit of togetherness and brotherhood in a container that has a character and identity, the ability to build a network with related units, as well as the ability to remain sterile from various temptation and interests. Now, it is time MGMP be dynamic motion in intact and transformed itself into a total frenzy education is increasingly complicated, complex, and challenging.

MGMP emphasis on how to develop professional skills of teachers through the forum peers. During this forum colleague who has been there is a periodic MGMP gathered with the aim of encouraging an increase in the quality of teaching and teacher competence. However there are times when this board ran out of things to say because it is awaiting information from the trustees in this case the department of Education in their respective areas. MGMP are focused on the development of teacher competence are more operational and concrete.

For further professional development, Department of Education at provincial level sometime invites some teachers 
from regencies to attend a training or workshop. The focus can be general or specific. The general subject, for instance, the government disseminates new policies in curriculum or approaches in teaching. While, the specifically can be related the innovation in teaching or materials development per subject-matter. Later, the participants will be the disseminator to their colleagues at school to spread out the information until the rural areas. Unfortunately, the application of training result-gained is hard to make it real because the limited school facilities and resources.

The successful of teacher professional development is usually handicapped by many factors. The problems come from the programs and activities which are not in touch with the specific need in teaching and learning. The level of participation and motivation of teachers to share and disseminate the experience is interrupted by communication. Meanwhile, some districts face geographical problem to take part in the programs.

Nowadays, the trend of teacher professional development which is focused by the government is improving the academic qualification of all two or three years-diploma degree to bachelor degree. Even right now, the increased numbers of teacher have master and doctoral degree as means to improve the quality of profession and career opportunity.

\section{Methodology}

This study conducted exploratory mixed methods design (QUAL-Quan Model) where qualitative data is more heavily weighted. According to Creswell (2012), this method allowed us to sequence data collection where firstly collecting qualitative data (interview and observation) then followed by quantitative data (survey). The integration helps to achieve rigorous interpretation and to ensure the consistency of both strands (Teddlie and Tashakkori, 2009).

In addition, triangulation is used to collect data through interview, observation, and survey in order to get quality data to enhance the accuracy or credibility and to ensure validity of study. The presentation of findings in this research combined three main sources from questionnaires, interviews, and observations in classroom and field notes. As Creswell (2012) defined triangulation as a process of corroborating evidence from different type of data. Triangulation may involve comparing data on the same behavior from researchers who possibly adopted different roles, times, sub-settings or subjects, and methods (Baharin Abu, 2000). The combination helped to formulate conclusive evidence to support findings in this study.

The population of this study involves civil servant teachers from public state high schools in South Sulawesi, Indonesia. The population is determined using Random Cluster Sampling (single cluster) by considering the large number of population, the geography, and the efficiency of cost and time. Clustering represents the area of South Sulawesi into south and north zones. One zone consists of 12 regencies. Then, three regencies are chosen in each zone by using simple random technique. The drawing of south zone produced Gowa, Bone, and Pangkep regencies and the next round comes out Pare-Pare, Sidrap, and Pinrang. The sample is 331 from 2367 population which determined based on Krejcie and Morgan's (1970) table.

In collecting quantitative data, researcher administers survey or questionnaire to answer the hypotheses about the statistical significant of demography factors with professional characters. The data were analyzed using t-test and Anova. For qualitative data, 12 teachers were chosen by using purposive random sampling because they have broad knowledge and more experiences. Open ended questions in a semi structured interviews were proposed in describing professionalism practices, learning activities in professional development, the supports, and the constraints toward professional teachers. Classroom observation was also done to get a description of pedagogical skills and field note to gain teachers' behavior-attitude.

\section{Findings Analysis}

The main questions of this study are related to "Teachers professionalism and professional development practices among senior high school in South Sulawesi, Indonesia". The research questions then divided into six parts to get more completed description. The questions are: (1) is there statistical significant difference between attitude-behavior, pedagogic competence, and learning activities as the characters of teachers' professional practice with the demography factors (gender, age, years of experience, and education professional qualification), (2) How is the level of pedagogic competence of senior high school teachers, (3) what are the characteristics of teachers' professional as being practiced among senior high school teachers, (4) how do the professional development activities such as self-learning, mentoring, and in-service training effective in promoting teacher professionalism, (5) what factors supporting teacher professionalism and teacher professional development, (6) what are the constraints in 
promoting teacher professionalism and professional development. However, in exploring the answers of the questions, more approaches were needed to get a rich and dept information from the respondents to explain the findings.

\subsection{Teachers’ Professional Characters and Demography Factors}

In this study, the significance between demography factors and professional practice of teachers in attitude-behavior, pedagogic competence, and learning activities were identified to see the difference. The analysis of gender, age, teaching experience, and education professional qualification help to describe the characters of teacher professional as being practiced. This information is helpful in making decision for the quality improvement of teacher professionalism and professional development. It also shows the trend of changing through the time in practice professional characters.

The result showed that there were significant different of gender with professional characters in attitude-behavior $(\mathrm{P}=.006<.05$, significant $)$, pedagogic competence $(\mathrm{P}=.890>.05$, no significant), and learning activities $(\mathrm{P}=.348>.05$, no significant). Mean while, the age and attitude-behavior ( $\mathrm{P}=.274>.05$, no significant), pedagogic competence $(\mathrm{P}=.751>.05$, no significant), and learning activities $(\mathrm{P}=.683>.05$, no significant). The years of teaching experience statistically have no significant different in practicing the characters of professional such as behavior-attitude $(\mathrm{p}=.138>.05)$, pedagogic skills $(\mathrm{P}=.236>.05)$, and learning activities $(\mathrm{P}=.685>.05)$. The last is between education professional qualification with attitude-behavior $(\mathrm{P}=.028<.05$, significant), pedagogic competence $(\mathrm{P}=.211>.05$, no significant), and learning activities ( $\mathrm{P}=.043>.05$, significant).

\subsection{The Level of Pedagogic Competence}

Pedagogic competence related to a series of teaching activities done to achieve a successful learning and teaching process in the classroom. The teachers need to assess and reflect all time to understand their mastery level of this competence. It can be measured through appraisal using some indicators as evidences by competent people or do self-reflection. In this study, the teachers of senior high schools in South Sulawesi, Indonesia have good level of pedagogic competence even though, some aspects of this area require an improvement. Two areas of observation in the evidences of structuring teaching and teaching skills still have low competence. The skills cover the ability in using visual aids, integrating technology to match the objective, and applying suitable evaluation techniques.

The refined of evidences in teacher pedagogic skills can be identified from their capability in connecting the lesson with students daily life, making note to highlight the main points of teaching materials combining the supporting of ICT in displaying the content. Although teachers have sufficient knowledge on subject teaching, they have to know contemporary information or new things in correlating with other sciences. In teaching skills, applying various techniques and strategies are crucial to avoid students' boring in learning. Meanwhile, they have to help students to build the belief in mastering the competency standards of each subject. It promotes students to learn more and more or encourages self-enquiry to catch the aims of learning. At last, sense of humor relief to decrease the burden and maintain the stability and conduciveness learning environment. Generally, the strength of teachers in managing the activities in teaching are vary in each evidence so that the less one indicator can disrupt and reduce the effectiveness of the learning process.

\subsection{The Characters of Professional Teachers}

Generally, the findings indicated that the teachers of senior high school practice the characteristics of professional in their fieldwork as teacher and educator. In this case, the practices focused on their effort to show their behavior and attitude in performing their duties and in helping students to achieve knowledge and skills for life. The professional practices are showed in improving pedagogic skills in teaching and seeking professional development activities which contributing to their professionalism. They performed good commitment and responsibility toward the students and profession. However, most of actions need to maximize as totality of dedication for young generation. The pattern of work relationship using conscience, love, humanity in maintaining better situation, flexibility cooperation, communication, and respect among school communities can be more promoted. Teachers also thought that discipline in carrying out tasks indicated altruism principle above all private needs.

What else teachers have when entering the class? Teachers need pedagogic competence in supporting the successful of teaching and learning effectively. Related to the practice of pedagogic traits as a part of professional behavior, teachers showed their management skills in designing the materials, strategies in communication, technique of evaluation to achieve the aims of curriculum. The ability of teachers in managing learning resources and learning activities required to be improved continuously. The skills on methodology and strategy are very helpful in creating active, creative, and joyful learning activities. Professional practices in this area focused on developing content 
knowledge based on curriculum, preparing learning resources including ICT-based media, suitable teaching method for meaningful learning, and accurate evaluation for better output.

\subsection{Learning Activities as Commitment for Continuous Improvement}

Learning activities for teachers enhance teachers' professionalism especially elevating knowledge, skills, and practice in teaching. It also leads to a better behavior and attitude through communication and sharing experience. The activities of service trainings, mentoring, and self-learning kept the trusty, confidence, and commitment for continuous improvement personally and socially. These opportunities refresh and improve knowledge and skills which are impact on changing practice in teaching. Unfortunately, the new knowledge gained from the learning activities cannot be fully applied because of the limited facilities at school. The disobedience of effective features in professional development obstructed the teachers to bring about changing, producing new knowledge, and solving problem-faced.

Teachers are familiar to do formal learning activities in Teacher Subject Forum or Musyawarah Guru Mata Pelajaran (MGMP) in the district area of teachers' workplace. Teachers also joined in service trainings which are usually done to introduce new policy and method in teaching and learning activities. Seminar and workshop supplemented their activities for better performance in the classroom. Mentoring or "tutor sebaya" of experienced teachers to their junior promote the status of teaching profession for quality output. The most common way for high quality teaching skills, knowledge and career are achieved through improving teacher qualification to higher level. Some of them are actively reading any sources from books, magazine, and scientific writings and so on.

This study also explored the effectiveness of teachers' learning activities in professional development in term of content focus, the duration of time, coherence with the policy, participants' active learning, and their collective participation. In the practice, teachers exposed that not all the program focused on certain subject and the participants consist of many different subject background. Teachers also felt difficult to share and to discuss the materials because of the limited time even decreased the duration for several days. In the coherence of program with the aims of government cover too general and not specific in the need of teachers in teaching and learning. One thing is the connection with local content and local wisdom. The next dimension is the active learning of participant where some of activities just invite participants to listen a speech but contrary, it is effective when the speaker let them problem-solving and formulating their needs for the class. The changing practice also recommends to the design of program in which the stakeholders need to involve the teacher in planning and determined the contents.

\subsection{The Government Support on Teacher Professionalism and Professional Development}

Developing and creating professional teachers are complicated where many aspects should be considered. The government as main stakeholder is responsible to formulate a policy that supporting the growing of teacher professionalism. Teachers have rights to get facilities, securities, and opportunities to keep their profession. They are supported to get access for continuous learning through in-service training, higher education, and prepare various learning activities independently. They need sufficient budget for teaching activities and raising their welfare to keep the consistency on duties at school. The assurance of career guidance creates secure life for teachers.

On the one hand, all parties have responsibility to maintain teacher emotion and motivation as moral support in creating quality human resources. It encourages self-confidence, altruism spirit over personal interest in gaining the national aims of education in Indonesia. These moral factors influence to work environment in collaborating school communities such as teachers, staffs, principal, students, and students' parents to be successful. In this case, the local house of representative member and government as policy makers are expected to initiate better treatment for teacher career. They need appreciation as social human being and rewards in welfare as professional.

In reality, the balancing of priority between the needs and financial allocation to fulfill the infrastructures are still inconsistence. The financial is dominantly spend for salary compared to the learning needs in the classroom like full furnished and representative building with good safety standard. The handicaps were the lack of funds to prepare and integrate technology devices in learning activities. The most important is allocating enough money in offering the opportunities in developing their competences and the maturity in making a decision for students and career. More than three millions of teacher personnel are waiting the real action in developing their profession.

\subsection{The Constraints of Teacher Professionalism and Professional Development}

Indeed, many problems stayed around teachers on the way to professional and competent based on their field of teaching. Time management, cost, bureaucracy system, and the internal factors of teachers such as personality, motivation, and commitment are still the main impediment challenges of teaching profession. Teachers did not have the same opportunities to learn and maintain the level of professionalism by participating in professional 
development activities. The government admitted their limitation to train teachers in a planned program because of low cost budgeting from the local and central government. The time also becomes main handicaps in achieving better practice because it has limited space to practice in massive materials. They were lack of time to reflect and evaluate the content based on the real experience in the classroom. In implementing effective learning, teachers should be involved in determining the duration, strategy, and content based-experienced in the class to recover their problems. Thus, the participants actively sharing to find out the solution not just come listening speech.

At the policy level, the stakeholders are less aware on teacher needs physical and mental in the fast changing and competitive era. The implementation of law in state system practically left far behind the realities. Their needs in promoting and supporting learning activities in terms of training, workshop, mentoring, self learning as a part of lifelong learning spirit are less welcome as priority. In-service and on-service training are not intentionally done to keep the consistency of motivation and commitment of teachers toward the profession. As their experience, they felt like new born baby when getting new motivation, knowledge, and experience. There are still many home works for government, teachers, and society to be refined, revised, and reworked to bring the nation ideals in reality.

\section{Discussions}

\subsection{Teacher Professionalism Practice}

Being a professional, teachers have to learn and sharpen this skill in achieving good outcomes for students. Having low pedagogic skills in teaching make teachers are difficult to sustain student attention in learning (Chapuis, 2003), to cater different students learning styles, and to engage into cognitive challenging and relevant curriculum (Kalantzis and Cope, 2003). It also involves how to develop strategies for sustaining and gaining the interest of students, enabling to learn in fully capabilities, and encouraging disaffected. How can teachers lead their students to mastery high order thinking skills, integrate or connect the knowledge, and involve the students actively in learning without pedagogic skills (Murdoch, 1998). That is why pedagogic competence needs to be recognized as broader talent and skills for the successful teaching and learning.

Teachers should be applying variety of learning activities. Each lesson topic needs multiple teaching strategies based on the content and objective to help into deeper comprehension, greater retention, and better achievement (Sternberg, 2006). A strategy is effective if it is suitable with the topic and the time available (Schooling et al., 2010). A good teacher must be able to see what kinds of activities will interest as they learn a concept or skill and improve student achievement (Jablon and Wilkinson, 2006). The best practices in managing the classroom with variety activities help teachers create conducive learning environments that motivate the involvement of students in learning actively. The teachers need to show a changing in their practice as they practiced in the observation findings. They need to improve teaching skills at all aspects. One of teachers' tasks is connecting the lesson content with daily life (Pettey-Taylor, 2004) as the technique in transferring the knowledge meaningful to students. Teachers also have to be familiar and skillful on ICT in facilitating the students' learning. This trait reminds teachers to equip students with life skills as a tool to earn a living.

Teachers also required practice of professional characters in behavior and attitude. In this study, teachers performed very high enthusiasm for teaching but they are less flexible when working with students and colleagues. Holt (1964) highlighted that teachers have to reflect their knowledge, enthusiasm, and responsible to create the desire learning environment. Nevertheless, the teachers who taught at schools in surveyed area mostly practice the professional behavior and attitude well. It can be identified from the questionnaires where some items have above the average mean. This study can be a reminder for teachers to be aware of their actions because it can be seen clearly. Behavior and attitude are two characteristics of professional teachers in developing stronger sense of professionalism (Kramer, 2003). Because of that, attitude is everything (Hursh \& Reding, 2000) and behavior is very important to recognize and to do their roles in their life (Wong and Wong, 1998).

In daily life, teachers are imitated (ditiru) and replicated (digugu). It is reasonable why teachers must demonstrate and promote positive values, attitudes and behavior that they expect from pupils. Some exemplary behavior and attitude such as flexibility to students, humorist, patience, fair, enthusiasm, care, and interest contribute to the effectiveness of teaching (Malikow, 2005; Harslett et al., 2000; Liakopoulou, 2011). In other words, they must act as role models in the classroom. Teachers behave as moral educators at schools and contribute in promoting values thorough different subjects in the curriculum. Teachers are expected to display good characters because they are influential actors in the lives of students (Silver et al., 2005). Public still suppose teachers to transmit the values of such as honesty and fairness, and to adhere to professional ethic of conduct. The exemplary teachers in behavior and attitude 
has wisdom to know right from wrong, trustworthy, honest, fair, responsible and respectful, admit weaknesses and learn from mistakes, and commit to live on these principles forever. Teachers' character can be seen on how they treat and teach students (Lumpkin, 2008). By showing positive behavior and attitude, teachers play an essential role in assisting students learning and pertaining moral-reasoning process.

Professionalism closely related to the quality practice of a profession where the aspects of demography such as gender, age, years of experience, and education professional qualification can be considered. For Examples, some studies suggest that female is frequently less confident in their own abilities than male (Tavani and Losh, 2003). In many countries, female teacher tend to have insufficient or lower qualification and minimum training standards then male teacher. But in Indonesia, the government performs equality of gender in teaching profession for example a chance to involve in professional development or be a leader at school (Hapsariputri, 2010). On the other hand, the age of teachers have no significant with the practice of professional characters. This is in line with the researches of Landy et al. (2005), McEvoy and Cascio (2006) who mentioned that age has no influence on the quality of work. Teaching experience also has no significant difference although this phenomenon might have relationship to working conditions, facilities, and administrative support (Johnson et al., 2001). Kosgei et al. (2013) also asserted that teaching experience did not significant in the effort improving students' achievement. Mean while, education professional qualification is significantly different with practice of professional characters. It is relevant with the assumption that the more study the more knowledge and lead to be better in attitude, behavior, and performance in increasing student achievement. As a professional, academic professional qualification has a proportional relationship with mastery of subjects and the expectation of success in learning process (Nainggolan and Sunaryo, 1991). Advanced degrees such as master and doctor have positive effect on teacher (Rice, 2003; Wayne and Youngs, 2003). It is hoped that findings on the demographic variables to overall characteristics of professional practice applied to the area in which the study was conducted.

\subsection{Learning Activities in Professional Development}

Teachers' participation in professional development activities significantly showed positive impacts on teachers' beliefs and practices, students' performance in learning and on educational reforms in general (Cohen and Hill, 2000; Villegas-Reimers, 2003; Wenglinsky, 2000, 2002; Wiley and Yoon, 1995). Relevant activities include; improving qualification, refreshing their knowledge and understanding of subjects field, practicing on how to teach students with different background, developing practical competences and skills, learning new teaching methodologies and employing learning innovations and technologies, improving professionalism in ethics, and providing knowledge and skills to anticipate the dynamic society changing (Perraton et al., 2002).

In this study, professional development as one of the core lifelong learning has great impact in teaching practice and achieving students' needs. This is a space for teachers learning which is needed to equip and support sufficient knowledge and skills to solve the problem in teaching and learning (McAteer et al., 2005). It is useful to fulfill all their needs to compete in modern era and in the complexity of life. Teachers are not able to bring their students success without having broad content knowledge, skills, and experiences to practice. They are doubtful to meet new demand or minimal standards for student learning or to participate in solving educational problems without having an access to get learning opportunities at every level in their career (Ball \& Cohen, 1999).

In line with the growing awareness on education quality need in Indonesia, the society should benefit from an increasing education quality and thus be able to become active members of knowledgeable community. Society requires a profile of skills and competent teachers to accompany their future in the process of education, developing new skills and expectations for young generation (Suffean Husin, 2008). As the response, the society must take part in ensuring the elevating of quality, enhancing their job assurance, promoting better changes, activating their role as change agents and in general recognizing, teachers play their role in the implementation and intellectual dissemination reforms requires a high quality professional identity. According to Alton-Lee (2003) and Gurney (2007), quality teachers in teaching acquired by providing enough time and encourage learning activities as valuable opportunity to learn. It is supported by Quint (2006) that when teachers meet regularly to discuss their teaching, it impacts positively on student achievement.

By cooperating with society, the improvement of access and quality of professional development programs for teachers must be a top priority to sharpen their creativity and innovation in Indonesia and other developing countries. According to Schleicher (2012) school needs to nurture creativity and innovation as the hope for solving employability, crises of personal and social. The knowledge gained today will be commodity available for someone else tomorrow. Surprisingly, there are still many teachers having limitations and constraints which are actually can be handled such as time, cost, opportunity to learn, and bureaucratic matters. Of course, they cannot stand alone but 
need the involvement of society, businessman, and stakeholders. A high level of collaboration among them brings a successful change at school (Waldron and McLeskey, 2010).

In many literatures, professional development is considered a medium for teachers to elevate their knowledge and skills in teaching. If it is organized well from planning, process, and evaluation, teachers will get the benefit when they are in the real teaching practice. It can maximized teachers' learning when designing into strong content focus, active learning approach, connected to policies and curriculum, sufficient time to reflect, and collaborative participation (Cohen \& Hill, 2001; Garet, Porter, Desimone, Birman, \& Yoon, 2001; Penuel, Fishman, Yamaguchi, \& Gallagher, 2007). The successful of a learning program bring a changing to the way in conducting teachers' duties and keep the status as professional. The effectiveness can be highlighted from the core features below;

Content focus, the content of learning activities must be directed to enhance teachers' comprehension on subject matter they teach combined with a range of strategies which allow students' learn the contents (Victoria Education Department and Training, 2005), and how to assess the learning (Brandsford et al., 2000). Teacher admitted that many programs are less specific on subject area and teaching method. This is contra with King and Newman's (2004) opinion that teachers must understand their subject-matter content well enough to anticipate misconceptions of students and engage them a wide range of instructional strategies in learning.

In Indonesia, the teachers-subject forum or MGMP has strong focus on specific subject matter compare with other programs but it is no longer because of budgeting problem. Formerly, the government of Indonesia encouraged this activity to improve teachers' ability to plan, implement, and evaluate teaching and learning activity. It also provided opportunity to discuss problem faced, share information, experience, and develop cooperation among teachers and schools (USAID-DBE-3, 2005). This forum promotes teacher to learn the subject content actively, explore various knowledge and experience, and strength professionalism among their community (Lewis et al., 2004 and Perry \& Lewis, 2009).

Duration, another characteristic of effective professional development is providing sufficient time for teacher to share, practice and reflect enhancing teachers to appreciate their roles and responsibilities in the classroom. One of big mistake is usually done by cutting down the time from the prior schedule. Some researches show that teaching practice more likely improved when teachers have more time spend in professional development (NSDC, 2009b; Porter et al., 2003; Quick et al., 2009). Effective is typically associated when involving significant numbers of contact hours or offering over a long period of time in professional learning activities (Guskey, 2002). In traditional forms such as in-service training and workshops had a positive impact on teaching practice and outcomes of student learning when they involve teachers for many hours (Quick et al., 2009). Teacher should realized that a continual process over the time produce better learning outcomes to change in teaching practice (Fullan, 1995; King \& Newmann, 2004; Prochaska, DiClemente, \& Norcross, 1992; Lieberman \& Pointer Mace, 2008; Senge et al., 2000).

Coherence, the contents of effective professional development require to see the big picture related to the goal and policies in education. It must be coherence with the goals of school improvement plan or state learning standard (King and Newmann, 2004). In this study, teachers admitted that too much discussing about the policy of new curriculum implementation. Quick et al. (2009) asserted that teachers get more valuable experience when the content connected to school goals. Another point of coherence is the consistency to follow up what the teachers have learned from the prior professional development. Cohen and Spillane (1992) stressed that teachers can be facilitated to improve their teaching practice if the content has a coherent to the goals based on national, state, and local frameworks.

Active learning, there are many ways of promoting active learning in professional development such as mentoring, study group, and coaching (Quick, Holtzman, and Chaney, 2009), simulation and role plays (Knowles, 1983; Tate, 2009), problem solving (Lieberman \& Pointer Mace, 2008; Knowles, 1983), sharing and discussion (Mundry, 2005; Quick et al., 2009; Tate, 2009; Lieberman \& Pointer Mace, 2008), visual representations (Tate, 2009), reflection (NSDC, 2009a; Quick et al., 2009), and application and follow through (Lieberman \& Pointer Mace, 2008; Porter et al., 2003; Quick et al., 2009). Sometimes, active learning needs social interaction (Guskey, 1995) and physical movement to support attention and memory (Tate, 2009). Teachers complained of some rigid activities where they just come listening a speech in the whole program.

Collective participation, Desimone (2009) defined it as the collaboration of teacher with stake holders organizing, planning, and selecting the content of learning activities. Teamwork in Professional learning contributes into the effectiveness to develop skills in improving students output. The different participants experience encouraged them to act in the role of mentor or coach, model in practice; help to provide of various resource materials; and facilitate the availability of research into effective teaching and learning (Desimone, 2011). There are many advantages they 
obtain such as visiting to other class or schools to observe innovative teaching practice, facilitate problem-solving between novice and experience teacher, encouraging openness in risk-taking, enlarging their link with each other, and so on (Firman, 2005). One example of the most effective ways to learn collectively is by observing or being observed. Here, each teacher receives valuable feedback from the observers. They can analyze and reflect all the information to grow their professionalism. The collectivity promotes an open discussion to build teaching skills confidently.

\subsection{Supporting Factors for Teacher Professionalism and Professional Development}

Discussing the kinds of supporting factors for teaching profession, it links with the policies of Indonesia government as the basis of implementation and practice in education system. Related to the school system Supports, firstly, principal, teachers, staffs and students' parents stated their commitment in the form of visions, policies, plans, and actions for long-term teachers' professional development and short-term crisis management. Secondly, they did distributing the task and responsibility to organize school programs to strength commitment, maximizing the role of supervisors in assisting teachers to promote teaching practice, and providing necessary teaching resources to achieve instructional goals. The third, high quality education is determined by many factors and indicators such as budget (financial), the means of education and learning (infra-structure), and the full support of government institutions (executive and legislative) to pick the assets of the nation's education future (Rafiuddin Afkari bin Hj. Abdul Fattah, 2010). Some kinds of support such as policy, moral, infrastructures, and financial will discuss further below.

\subsubsection{Stake Holder Policy}

The government of Indonesia entered the new era in education by launching the law for teachers and lecturers No. 14/2005. Teachers expected so much a new perspective from their status and welfare as professional in their field. Related to professional status, the government encourages fulfilling the standard of education qualification, competences, certification, and health. For the next step, the central government mandate autonomy to each province and regency to follow up the implementation of the law. The local government required to issue new regulations as legal formal for teachers and stake holders (National Education Department) in taking action to meet their needs. Government need to plan Five-Year Education for Development in determining priorities programs that can solve a variety of problems in achieving the target of Education, governance, and various problems encountered in the field (Rafiuddin Afkari bin Hj. Abdul Fattah, 2010). Strategies and patterns of educational development will become more sophisticated and advanced if the role of government institutions, house of representative and public hands in hands to realize the educational programs seriously.

\subsubsection{Moral Support}

In line with the harder of teachers' duty and responsibility, all sides required to keep the stability of teachers' moral and emotion. According to Acker (1992) and Blackmore (1996) stated that political condition offered two choices on teachers namely caring more or more difficult. Get promotions and awards in accordance with the duties and job performance; obtain protection in carrying out the duties and rights of intellectual property; get the opportunity to improve competence; obtain a sense of security and safety assurance in performing the task; have freedom to associate in professional organization; have the opportunity to play a role in determining education policy. Moral support constructs teacher motivation as Tittle (2006) and Boyd et al. (2003) concluded that motivation is important in teachers learning, attract, and sustain their involvement in high dose. Teacher will never excite since the award given is still not promising and providing prestigious for anyone who involved in the education process. This is in line with some evidences that higher salaries and incentives influence the quality of teachers (Wilson, 2009; Figlio, 1997; Loeb \& Page, 2000; and Ferguson, 1991). Ajila and Abiola (2004) stressed that rewards or incentives influence to do better on a job, raise a sense of commitment, and useful to improve performance.

\subsubsection{Infrastructure Support}

Facilities and infrastructure of the school is a learning resource center of students that determining the success in learning process, and in improving the quality of education. Khan and Iqbal (2012) found out that physical facilities help teachers and students to have effective teaching and learning process. Procurement of reference books, laboratory equipments, ICT and other teaching resources by the central government was addressed and propagated to meet the demands of curriculum. Inadequate facilities significantly influence curriculum target and learning outcomes (Lyon, 2012 and Wilm, 2000). The facilities and infrastructures are acquired and utilized to support learning fluency duties of professionalism. This is the concern of teachers in South Sulawesi, Indonesia.

\subsubsection{Financial Support}

The successful of organization in operating the elements of duties depend on the sufficient of cost or budget. The 
allocation of each segment such as salary or incentive and procurement of goods and services was done to make sure the process of activity run well. In education system, the central and local governments must provide a budget for welfare, improvement of academic qualification, certification of teachers for in-service teacher education, and tools for teaching and learning process (Rowden, 2011). State prioritize education budget at least 20\% (twenty percent) of the budget revenue and expenditure of the state and local government budgets to meet the needs of national education since 2009-2012 (Supardi, n.d). Except the government, public investment in education system should be opened in financing education include hiring well-trained and well-paid teachers and administrators (Action Aid, 2005; Oxfam, 2003; UNATU, 2010). Funding as one of Educational resources is not everything, but teachers and staffs can do many things to improve the quality of education with the availability of adequate funds (Kotler et al., 1997). Then, financial support in professional development, school-based in-service training and other link training and upgrading used as strategies in developing human resource according to a career-path structure. Thus, it is clear that the good allocation of education funds leads to the achievement of quality education. It is not spent solely for personnel expenditure or expenditures for salaries and allowance, but it should be proportional for expenditure on salaries, capital, and operational.

\subsection{Constraints Factors for Professionalism and PD}

Nowadays, the process above only presents external factors which are weighty focus on administrative matters. The less efforts set aside the internal factor such the commitment, behavior and attitude of teachers as determination of keeping and maintaining individual stability. In the process of developing teachers, the government has to broad the concept of in-service programs and to support a growth of continuum participatory learning that is closely tied to the realities of classroom needs (Wils and O'Connor, 2004). Professional development activities or in-service programs ought to focus on specific training for pedagogy, subject content knowledge, and classroom management which is appropriate to teachers' current needs. Ongoing sharing of ideas, guidance and support, and care among teachers, support of school leader, and obtain sufficient free time to participate in training or workshop. Most of teachers all over the world felt that the majority of PD activities are "too short, unrelated to the needs of teachers and ineffective to upgrade teaching knowledge and skills (Villegas-Reimers, 2003).

Shorter programs such as school-based activities with ongoing mentoring and support should be considered, especially in education systems with a lack of training for teachers. Active in classroom action research, observe good practices and peer review in their teaching are good activities at school level (Jones and Son, 2005; Kirkey, 2005; McIntosh, 2005). These activities impart high skills on subject and pedagogies, a concept of how adults and children learn. Teachers need time to reflect with colleagues and students about teaching practice. They required initial preparation in their methodologies, language fluency for teaching instruction, instructional materials, and strategy for classroom management before entering the class. This is in line with Podhorsky and Moore (2006) who suggested in creating teacher learning program to repair learning and teaching practice. It will be useful to overcome the students' failure in learning. For effective results, inspectorate supervisors, head teachers, and peers follow up by performing classroom supervision to improve individual teacher performance in the classroom and collective performance of education system (OECD, 2011).

\section{Summary of Discussion and Conclusion}

Evidence from analyses shown various perceptions of teachers related to the concept of professionalism and professional development activities where the informants are the certified state senior high school teachers. It can be concluded that as professional teachers, they evinced to have exemplary behavior and attitude as characters outside and inside of the classroom among the students and colleagues. Toward the profession, the characters encourage in exhibiting their commitment and responsibility to do self improvement as real contribution for students learning. However, establishing an appropriate system of standards can help all teachers work towards both high standards and the same professional status.

Other efforts to bring teacher achieved professional status and effective professional learning activities are supporting with accountability bureaucratic system of local and central government through the policy of welfare and facilities based on their needs. Related to teacher competences, knowledge, and skills, various learning activities in professional development must be strengths and supported. The seriousness and commitment from stakeholders sometimes become a big question because it is only on white paper. The consistency in supporting teachers encourages the innovation in teaching practice for the improvement of personal and career as the member of school communities. The assurance, security, and guarantee from all parties stimulate teacher creativity to change in practice at the level of individual, school organization, and social life. This research suggested considering demography factors. The conclusion in Figure 
1 below can be transferable as alternative model in developing teacher profession.

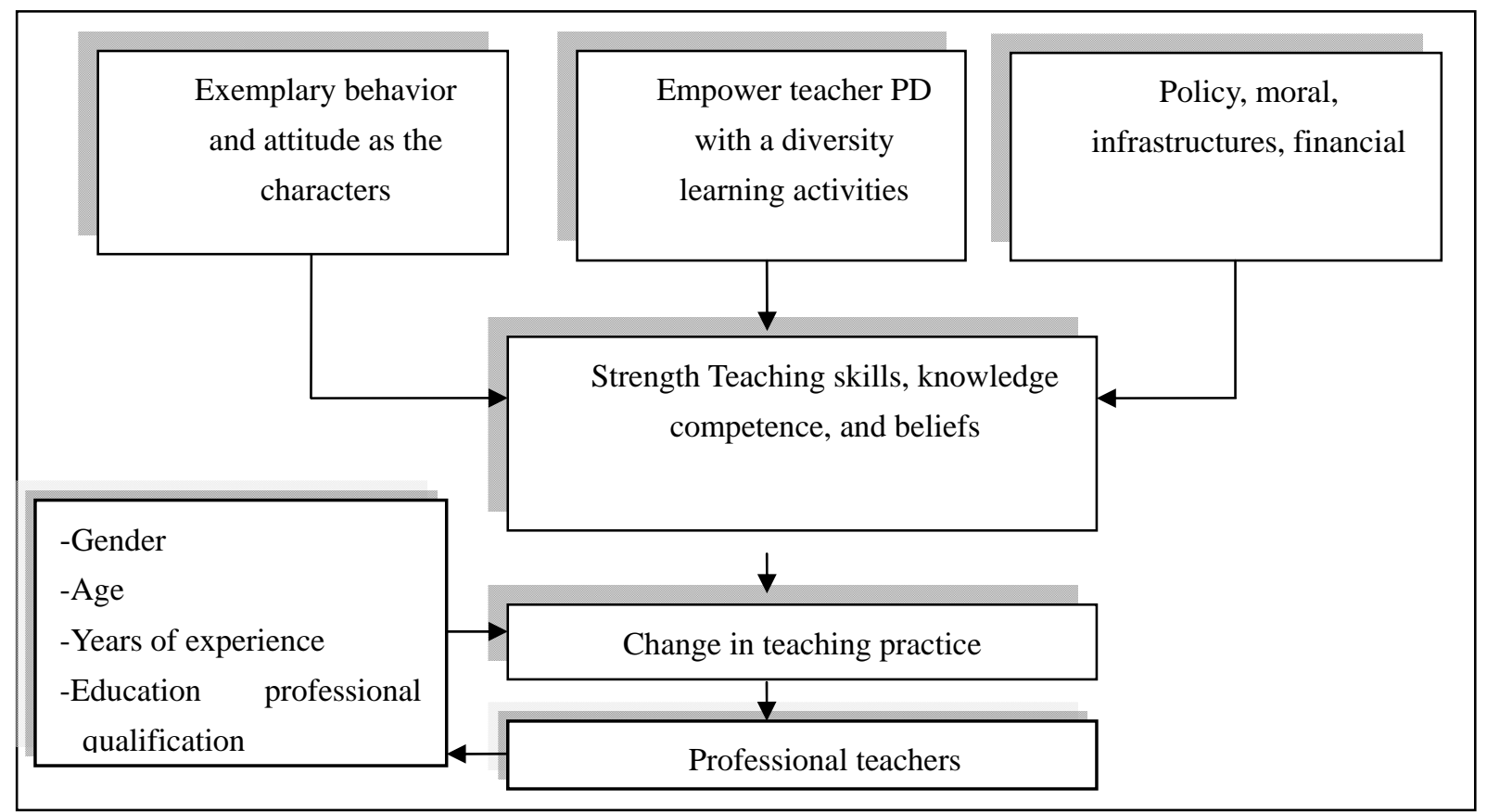

Figure 1. Model of Teacher Development

\section{References}

Acker, S. (1992). Creating Careers: Woman Teachers at Works. Curriculum Enquiries, 22(2), 141-163. http://dx.doi.org/10.2307/1180030

Action Aid. (2005). Contradicting Commitments: How the Achievement of Education For All is Being Undermined by the IMF, By Akanksha A. Marphatia and David Archer, Action Aid International.

Ajila, Chris \& Abiola, Awonusi. (2004). Influence of Rewards on Workers Performance on an Organization. Journal of Social Science, 8(1), 7-12.

Ali, M.A. (2000). Supervision for teacher development: an alternative model for Pakistan. International Journal of Educational Development, 20, 177-88. http://dx.doi.org/10.1016/S0738-0593(99)00020-6

Alton-Lee, A. (2003). Quality Teaching for Diverse Students in Schooling: Best Evidence Synthesis. Wellington: Ministry of Education.

Baharin Abu. (2000). Teaching Effectiveness and Staff Professional Development Programs at a Higher Learning Institution in Malaysia. Unpublished PhD thesis, School of Education the University of Birmingham.

Ball, D. L., \& Cohen, D. K. (1999). Developing practice, developing practitioners: Toward a practice-based theory of professional education. In G. Sykes \& L. Darling-Hammond (Eds.), Teaching as the Learning Profession: Handbook of Policy and Practice, pp. 3-32. San Francisco: Jossey-Bass.

Bjork, C. (2003). Local Responses to Decentralization Policy in Indonesia. Comparative Education Review, 47(2), 184-216. http://dx.doi.org/10.1086/376540

Blackmore, J. (1996). Doing Emotion Labor in the Education Market Place: Stories from the Field of Woman Management. Discourse: Studies in the Cultural politics of Education, 17(3), 337-349.

Boyd, Donald J. et al. (2006). Complex by Design: Investigating Pathways into Teaching in New York City Schools. Journal of Teacher Education, 57(2), 155-166. http://dx.doi.org/10.1177/0022487105285943

Bransford, JD, Brown, AL., \& Cocking, R. (2000). How People Learn: Brain, Mind, Experience, and School, Committee on Developments in the Science of Learning, National Research Council, National Academy Press, Washington DC. 
Chapuis, Lea. (2003). Pedagogy: Embedding Learning Technologies (Modul1). Australian Education and Training.

Cohen, D., \& Hill, H. (2000). Instructional policy and classroom performance: The mathematics reform in California. Teachers College Record, 102, 294-343. http://dx.doi.org/10.1111/0161-4681.00057

Cohen, D. K., \& Hill, H. C. (2001). Learning Policy: When State Education Reform Works. New Haven, CT: Yale University Press. http://dx.doi.org/10.12987/yale/9780300089479.001.0001

Cohen, D.K., \& Spillane, J. (1992). Policy and Practice: The Relations between Governance and Instruction. Washinton D.C.: American Educational Research Association.

Creswell, J. W. (2012). Educational Research: Planning, Conducting, and Evaluating Quantitative and Qualitative Research (4 ${ }^{\text {th }}$ Edition). Boston: Pearson Education, Inc.

Desimone, L. M. (2009). Improving impact studies of teachers' professional development: Toward better conceptualizations and measures. Educational Researcher, 38(3), 181-199. http://dx.doi.org/10.3102/0013189X08331140

Desimone, L.M. (2011, March). A Primer on Effective Professional Development. Kappan, 92(6), 68-71.

Ferguson, R. F. (1991). Paying for public education: New evidence on how and why money matters. Harvard Journal of Legislation, 28, 465-498.

Figlio, D. (1997). Teacher Salaries and Teacher Quality. Economics Letters, 55, 267-272. http://dx.doi.org/10.1016/S0165-1765(97)00070-0

Firman, H. (2005). Peranan Kegiatan Piloting IMSTEP dalam Peningkatan Profesionalisme guru (The Role of Piloting IMSTEP in Improving Teacher Professionalism). Paper Presented at Exchange Experiences IMSTEP Working Group Conference, UniversitasNegeri Malang. September 5-6, 2005.

Fullan, M.G. (1995). The limits and the potential of professional development. In T. Guskey and M. Huberman (Eds.), Professional Development in Education: New Paradigms and Practices (pp. 253-267). New York: Teachers College Press.

Garet, M. S., Porter, A. C., Desimone, L., Birman, B. F., \& Yoon, K.S. (2001). What Makes Professional Development Effective? Results from a National Sample of Teachers. American Educational Research Journal, 38(4), 915-945. http://dx.doi.org/10.3102/00028312038004915

Gurney, Philip. (2007). Five Factors for Effective Teaching. New Zealand Journal of Teachers' Work, 2(4), 89-98.

Guskey, T.R. (1995). Professional Development in Education: In Search of the Optimal mix. In T. Guskey and M. Huberman (Eds.), Professional Development in Education: New Paradigms and Practices (pp. 114-131) New York: Teachers College Press.

Guskey, T.R. (2002). Professional development and teacher change. Teacher and teaching: theory and Practice 8(3/4), 381-390. http://dx.doi.org/10.1080/135406002100000512

Hapsariputri, W.M. (2010). Evaluating Teachers' Quality Improvement Policy in Indonesia: To meet the UNESCO-EFA criteria. Unpublished Master Thesis. Faculty of Technology, Policy, and Management: Delft University of Technology.

Harslett, M. et al. (2000). Teacher Perceptions of the Characteristics of Effective Teachers of Aboriginal Middle School Students. The Australian Journal of Teacher Education, 25(2).

Hurst, B., \& Reding, G. (2000). Professionalism in Teaching. Upper Saddle River, N.J.: Prentice Hall.

Ingersoll, Richard M. 2007. Misdiagnosing the Teacher Quality Problem. Research in Education Policy and Finance. University of Pennsylvania.

Jablon, Judy R., \& Wilkinson, Michael. (2006). Using Engagement Strategies to Facilitate Students' Learning and Success. Beyond the Journal. Retrieved from http://www.naeyc.org/files/yc/file/200603/JablonBTJ.pdf

Johnson, S. M., Birkeland, S., Kardos, S. M., Kauffman, E. L., Liu, E., \& Peske, H. G. (July/ August. 2001). Retaining the next generation of teachers: The importance of school-bases support. Harvard Education Letter, 6, 8.

Jones, P., \& Song, L. (2005). Action research fellows at Towson University. Retrieved from http://www.nipissingu.ca/oar/PDFS/V832E.pdf

Kalantzis, M., \& Cope, B. (2003). Designs for Learning (Draft 2003). RMIT. 
Kementerian Pendidikan Nasional. (2010). Rencana strategis Kemeterian Pendidikan Nasional 2010-2014. Jakarta: Indonesia.

Retrieved

from http://www.psp.kemdiknas.go.id/uploads/Statistik\%20Pendidikan/0910/index_sma_0910.pdf

Khan, Parveen \& Iqbal, Mohammad. (2012). Role of Physical Facilities in Teaching Learning Process. Interdisciplinary Journal of Contemporary Research in Business, 4(3), 210-216.

King, B., \& Newmann, F. (2004). Key Link: Successful Professional Development must Consider School Capacity. Journal of Staff Development, 25(1), 26-30.

Kirkey, T. L. (2005). Differentiated instruction and enrichment opportunities: An action research report. Retrieved from http://www.nipissingu.ca/oar/PDFS/V833E.pdf

Knowles, M. (1983). Adults are not Grown up Children as Learners. Community Services Catalyst, 13(4), 4-8.

Kosgei, Anita et al. (2013). Influence of Teacher Characteristics on Students' Academic Achievement among Secondary Schools. Journal of Education and Practice, 4(3), 76-82.

Kotler, P., Jatusripitak, S., \& Maesincee, S. (1997). The Marketing of Nation: A Strategic Approach to Building Nation Wealth. New York: The Free Press.

Kramer, Pamela A. (2003). The ABC's of Professionalism. Kappa Delta Pi Record, 40(1), 22-25. http://dx.doi.org/10.1080/00228958.2003.10516409

Krejcie, R.V., \& Daryle W. Morgan. (1970). Determining Sample Size for Research Activities. Educational and Psychological Measurement, 30, 607-610.

Lewis, C., Perry, R., \& Hurd, J. (2004). A deeper look at lesson study. Educational Leadership, 61(5), 18-22.

Liakopoulou, Maria. (2011). The Professional Competence of Teachers: Which qualities, attitudes, skills and knowledge contribute to a teacher's effectiveness?. International Journal of Humanities and Social Sciences, 1(21), 66-78.

Lieberman, A., \& Pointer Mace, D. (2008). Teacher Learning: the Key to Education Reform. Journal of Teacher Education, 59(3), 226-234. http://dx.doi.org/10.1177/0022487108317020

Loeb, S., \& Page, M. (2000). Examining the link between teacher wages and student outcomes: The importance of alternative labor market opportunities and non-pecuniary variation. Review of Economics and Statistics, 82, 393-408. http://dx.doi.org/10.1162/003465300558894

Lumpkin, Angela. (2008). Teachers as Role Model Teaching Characters and Moral Virtues. JOPERD, 79(2), 45-49.

Lyons. (2012). Do School Facilities Really Impact A Child's Education. An Introduction to the Issues. Retrieved January 24, 2012 from School Facilities.com/pdf/school\%20 Facilities\%20 facilities\%202012-01pdf

Maister, DH. (1997). True Professionalism. New York: The Free Press.

Malikow, M. (2005). Effective Teacher Study. National Forum of Teacher Education-journal electronic, 16(3), 1-9.

McAteer, M., Foster, R., Groves, J., Hallet, F., Jones, M., \& Rutter, T. (2005). Continuing Professional Development: Exploring the Impact on Teachers' Professional Practice and Pupil learning. Paper presented at BERA annual conference, University of Glamorgan, 14 - 17 September 2005.

McIntosh, J. E. (2005). Valuing the collaborative nature of professional learning communities. Retrieved July 42007 from http://www.nipissingu.ca/oar/PDFS/V82E.pdf

Misbahuddin. (2013). The Development of Teacher Profession. Thesis. Program Pascasarjana Universitas Negeri Makassar. April.

Mundry, S. (2005). Changing perspectives in professional development. Science Educator, 14(1), 9-15.

Murdoch, K. (1998). Classroom Connections, Strategies for Integrated Learning. Curtain Publishing.

National Staff Development Council (2009a). NSDC Standards: Learning. Retrieved June 30, 2009 from http://www.nsdc.org/standards/learning.cfm

Nielsen, Dean H. (1996). Reform to Teacher Education in Indonesia: Does More Mean Better?. Research Paper. World Bank Teacher Development Project.

OECD. (2011). Building High-Quality Teaching Profession: Lesson from Around the World. OECD Publishing Paris. 
Oxfam. (2003). The IMF and the Millennium Goals: failing to deliver for low income countries. Oxfam Briefing Paper No. 54, September.

Penuel, W. R., Fishman, B. J., Yamaguchi, R., \& Gallagher, L. P. (2007). What Makes Professional Development Effective? Strategies that Foster Curriculum Implementation. American Educational Research Journal, 44, 921-958. http://dx.doi.org/10.3102/0002831207308221

Perraton, H., Creed C., \& B. Robinson. (2002). Teacher Education Guidelines: Using Open and Distance Learning. Paris: UNESCO.

Perry, R., \& Lewis, C. (2009). What is successful adaptation of lesson study in the US? Journal of Educational Change, 10(4), 365-39. http://dx.doi.org/10.1007/s10833-008-9069-7

Pettey-Taylor, Sharon. (2004). Engaging and Supporting Students in Learning. The Professional Teaching Standards. New Teacher Center at The University of California, Santa Cruz.

Podhorsky, C., \& Moore, V. (2006). Issues in curriculum: Improving instructional practice through lesson study. Retrieved August 152007 from http://www.lessonstudy.net

Porter, A., Garet, M., Desimone, L., \& Birman, B. (2003). Providing Effective Professional Development: Lessons from the Eisenhower Program. Science Educator, 12(1), 23-40.

Prochaska, J. O., DiClemente, C. C., \& Norcross, J. C. (1992). In search of how people change. American Psychologist, 47, 1102-1114. http://dx.doi.org/10.1037/0003-066X.47.9.1102

Quick, H., Holtzman, D., \& Chaney, K. (2009). Professional Development and Instructional Practice: Conceptions and Evidence of Effectiveness. Journal of Education for Students Placed at Risk (JESPAR), 14(1), 45-71. http://dx.doi.org/10.1080/10824660802715429

Quint, J. (2006). Meeting Five Critical Challenges of High School Reform: Lessons from Research on Three Reform Models. New York: Manpower Demonstration Research Corporation.

Rafiuddin Afkari bin Hj. Abdul Fattah (2010). Peranan, Strategi dan Pola Pengembangan Pendidikan Mewujudkan Sumber Daya Manusia (SDM) di Inhil yang Berwawasan Maju dan Gemilang 2025. Telah Dibentangkan dalam Seminar Nasional "Wujudkan Tembilahan Kota Pendidikan Menuju Indragiri Berjaya dan Gemilang 2025, pada Disember 2011 Dewan Engku Kelana Indragiri Tembilahan Riau 2010. Universiti Tun Hussein Onn Malaysia.

Rivkin, S. G., Hanushek, E. A., \& Kain, J. F. (2000). Teachers, schools, and academic achievement(Working Paper W6691). Cambridge, MA: National Bureau of Economic Research.

Rout, M. (2007). Teacher Advised to Obtain Masters. The Australian, P. 25.

Rowden, Rick. (2011). Impacts of IMF Policies on National Education Budgets and Teachers: Exploring Possible Alternatives and Strategies for Advocacy. Education International Research Institute. June.

Saluling, Detty M. (2009). Basic Education for Poverty Alleviation: Community Perspectives from South Sulawesi, Indonesia. New Zealand: Victoria University of Wellington.

Sanders, W. L., \& Horn, S. P. (1994). The Tennessee Value-Added Assessment System (TVAAS): Mixed-model Methodology in Educational Assessment. Journal of Personnel Evaluation in Education, 8, 299-311. http://dx.doi.org/10.1007/BF00973726

Schleicher, A. (Ed). (2012). Preparing Teachers and Developing School Leaders for the 21st Century: Lessons from around the World. OECD Publishing.

Schooling, M., Toth, M., \& Marzano, R.J. (2010). Creating an aligned system to develop great teachers within the federal Race to the Top initiative. [Whitepaper]

Senge, P., Cambron-McCabe, N., Lucas, T., Smith, B., Dutton, J., \& Kleiner, A. (2000). Orientation. In P. Senge, N. Cambron-McCabe, T. Lucas, B. Smith, J. Dutton, and A. Kleiner (Eds.) Schools that Learn (pp. 3-58). New York: Doubleday.

Silver, R.B, Measelle, J.R, Armstrong, JM., \& Essex, MJ. (2005) Trajectories of Classroom Externalizing behavior: Contribution of Child Characteristics, Family Characteristics and the Teachers-Child Characteristics during the Transition. Journal of School Psychology, 43(1), 39-60. http://dx.doi.org/10.1016/j.jsp.2004.11.003

SMERU Research Institute. (2008b). Teacher Absenteeism and Remote Area Allowance Baseline Survey. SMERU, Jakarta, Indonesia. 
Sockett, H. (1993). The Moral Base fo Teacher Professionalism. New York: Teachers College Press.

Sternberg, R.J. (2006). Recognizing Neglected Strengths. Educational Leadership, 64(1), 30-35.

Sudarminta J. (2000). Tantangan dan Permasalahan Pendidikan di Indonesia Memasuki Millenium ketiga dalam A. Atmadi dan Y. Setiyaningsih (editor) Transformasi Pendidikan: Memasuki Milenium ketiga. Yogyakarta:Kanisius. Cetakan 1. Hal.3.

Suffean Husin. (2008). Pendidikan di Malaysia: sejarah, sistem, dan falsafah. Edisi 2. Kuala Lumpur: Dewan Bahasa dan Pustaka.

Supardi, U.S. (n.d). Arah Pendidikan di Indonesia dalam Tataran Kebijakan dan Implementasi. Jurnal Formatif, 2(2), 111-121.

Supriadi, D. (1998). Mengangkat Citra dan Martabat Guru. Yogyakarta: Adicita Karya Nusa.

Tate, M. L. (2009). Workshops: Extend Learning beyond your Presentation with these Brain- friendly Strategies. Journal of Staff Development, 30(1), 44-46.

Teddlie, C., \& Tashakkori, A. (2009). Foundations of Mixed Methods Research: Integrating Quantitative and Qualitative Approaches in the Social and Behavioral Sciences. Thousand Oaks, CA: Sage.

Tichenor, M., \& Tichenor, J. (2005). Understanding Teachers' Perspectives on Professionalism. The Professional Educator, 27, 89-95.

Tittle, C.K. (2006). Assessment of Teacher Learning and Development. In P. A. Alexander \& P.H. Winne (Eds.), Handbook of educational psychology ( $2^{\text {nd }}$ ed.), (pp. 953-980). Mahwah, NJ: Lawrence Erlbaum Associates.

Toh, K.A., Ho, B.T., Riley, J. P., \& Hoh, Y.-K. (2006). Meeting the highly qualified teachers challenge. Educational Research for Policy and Practice, 5, 187-194. http://dx.doi.org/10.1007/s10671-006-9008-4

Tuovinen, Juhani E. (2008). Teacher Professionalism: Viewpoints on Best Practice, the Case of Finland. AARE 2008 Conference, Brisbane, Australia.

UNATU. (2010). "Why Government Must Hire More Teachers and Increase Their Pay,” UNATU Newsletter: The Voice of the Teachers, Uganda National Teachers' Union, Kampala, August.

UNDP. (2011). Asia-Pacific Human Development Report. London: Routledge.

Unesco. (2006). Teachers and Educational Quality: Monitoring Global Needs for 2015. Institute for Statistics. Montreal: Canada.

Victoria Education Department and Training. (2005). Professional Learning in Effective School: The Seven Principles of Highly Effective Professional Learning. Melbourn: Victoria.

Villegas-Reimers, E. (2003). Teacher professional development: an international review of the literature. Paris: IIEP-UNESCO.

Waldron, Nancy L., \& McLeskey, James. (2010). Establishing a Collaborative School Culture through Comprehensive School Reform. Journal of Educational and Psychological Consultation, 20, 58-74. http://dx.doi.org/10.1080/10474410903535364

Watt, H. M. G., \& Richardson, P. W. (2008). Motivations, Perceptions, and Aspirations Concerning Teaching as a Career for Different Types of Beginning Teachers. Learning and Instruction, 18, 408-428. http://dx.doi.org/10.1016/j.learninstruc.2008.06.002

Wenglinsky, H. (2002). How schools matter: The link between teacher classroom practices and student academic performance. Education Policy Analysis Archives, 10(12), 1-36.

Wiley, D., \& Yoon, B. (1995). Teacher reports on opportunity to learn: Analyses of the 1993 California learning assessment system. Educational Evaluation and Policy Analysis, 17, 355-370. http://dx.doi.org/10.3102/01623737017003355

Willms, J.D. (2000). Standards of Care: Investments to Improve Children’s Educational Outcomes in Latin America. Paper presented at the "year 2000 Conference of Early Childhood Development” Sponsored by the World Bank, Washington, D.C., April, 2000.

Wils, A., \& R. O’Connor. (2004). Teachers matter: Teachers supply as a constraint on the global education transition. WP-04-01. Washington, D.C.: EPDC. 
Wilson, S. (Ed). (2009). Teacher quality (Education Policy White Paper). Washington, DC: National Academy of Education. Retrieved from http://www.naeducation.org/Teacher Quality White Paper.pdf

Wong, H. K., \& Wong, R. T. (1998). The First Days Of School: How to be an Effective Teacher. Mountain view. Calif.: Harry K. Wong Publications.

World Bank. (2010). Transforming Indonesia's Teaching Forces. Human Development East Asia and Pacific Region Report No. 53732-ID, Vol. 1. World Bank Office, Jakarta, Indonesia. 